\title{
SARCOPHAGID FLIES IN THE AUSTRALIAN MUSEUM \\ COLLECTION
}

\author{
BY \\ Professor T'. Harvey Johnston, M.A., D.Sc., \\ and
}

O. W. Tregs, M.Sc., W. and E. Hall Fellow in Economic Biology, University, Brisbane.

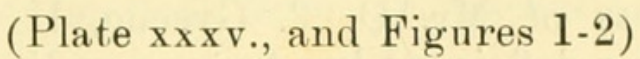

In a recent paper by us (1921) an attempt was made to determine the different species of Sarcophagid flies occurring in Southern Queensland by employing the characters of the copulatory organs in the male, a method first used by Böttcher for European species, and followed successfully by Parker and by Aldrich in dealing with North American forms. The present paper is a continuation of the work, some new Australian forms being described, while additional information is given regarding two known Hawaiian flies, and an account of a new Sarcophagid from New Zealand is included.

An examination of the specimens in the Australian Museum has enabled us to record a considerable extension of the known range of several species. The collection now includes, as far as we are aware, representatives of all adequately described Australian species except the following:-Sarcophaga delta J. and T., S. bancrofti J. and T., S. omega J. and T., as well as the following insufficiently described forms which we have not as yet been able to recognise:-S. prodatrix Walker, Sarcophagula pallichrus Thomson, S. pachytili Skuse and S. redipoda Olliff.

Sarcophaga prcedatrix was named from a female specimen fly from Port Essington, Northern Territory. Surcophagula pallichrus was described by Thomson as a Sarcophaga, his account being based on a female specimen collected in Sydney by the "Eugenie" expedition. Van der Wulp transferred it provisionally to the genus under which it is here listed.

Sarcophaga pachytili, a parasite of Australian grasshoppers, was described by Skuse as a Masicera, but Coquillet regarded it as a Sarcophaga and referred to it as such in a paper ${ }^{1}$ dealing with two American grasshopper parasites, S. opifera and S. davidsoni. S. opifera was made the type of a new genus Opsophyto by Townsend, ${ }^{2}$ but Aldrich in his monograph of the North American Sarcophagidæ does not recognise the genus. Skuse's figure suggests a Tachinid.

Sarcophaga odipoda is a nomen nudum, the mere name Tachina cedipoda having been used by Olliff for a fly bred from N. S. Wales grasshoppers. Mr. Froggatt ${ }^{3}$ in his work on Australian insects stated that Coquillet

1 Coquillet-U. S. Dept. Agric., Insect Life, v., 1. 1892, p. 22.

2 Townsend-Proc. Biol. Soc. Washington, xxviii., 1915, p. 23.

3 Froggatt-A ustralian Insects, 1907, p. 315. 
considered it to be a Sarcophaga, and in one of his own papers ${ }^{4}$ mentioned that it closely resembled $S$. aurifrons, but possessed a less golden colouration of the head and thorax. In a subsequent article on the "Eastern plague locust"5 he referred to Masicera pachytili, and to a second dipterous parasite, $S$. aurifrons, from which one may infer that he was satisfied as to the synonymy of S. cedipoda with Macquart's species. In view of this, together with the lack of any account by Olliff, we may safely remove $S$. aedipoda from the list of Australian Sarcophagidæ.

In our previous paper we attempted to clear up the confusion which existed in the synonymy of these Australian flesh-flies, but one important publication, that of Robineau-Desvoidy, ${ }^{6}$ was not at the time available. Through the kindness of Mr. C. T. Greene, U. S. National Museum, Washington D.C., this deficiency has been remedied, and has enabled us to reduce the synonymy even more.

The opportunity is also taken to correct some minor errors in our previous paper.

We desire to express to the Trustees of the Australian Museum our appreciation of their kindness in permitting us to examine the Sarcophagidæ contained in the Museum.

\section{Helicobia australis Johnston and Tiegs.}

Helicobia australis Johnston and Tiegs, Proc. Roy. Soc. Queensland, xxxiii., 1921, p. 50.

One male, paratype, Brisbane, Queensland.

2. Sarcophaga impatiens Walker.

S. impatiens Walker, List. Dipt. British Mus., 1849, iv., p. 828.

S. impatiens Johnston and Tiegs, Proc. Roy. Soc. Queensland, xxxiii., 1921, p. 52.

Several males and females, Brisbane, Queensland.

3. Sarcophaga tryoni Johnston and Tiegs.

S. tryoni Johnston and Tiegs, Proc. Roy. Soc. Queensland, xxxiii., 1921, p. 54 .

S. frontalis (in part) of Australian authors.

Two males and a female, paratypes, Brisbane, Queensland.

In our original description of this insect we stated: "Prescutellar acrostichals extend almost to end of scutellum," and " anterior femora . . . . . not hairy." This should be amended to read as follows : "Prescutellar acrostichals absent; anterior femora . . . . scantily clad with long hairs."

${ }^{4}$ Froggatt-Agric. Gazette, N.S.W., xvi., 1905, p. 20.

5 Froggatt-loc. cit., xviii., 1907.

${ }_{6}$ Robineau-Desvoidy-Essai sur les Myodaires, 1830. 


\section{Sarcophaga alpha Johnston and Tiegs.}

S. alpha Johnston and Tiegs, Proc. Roy. Soc. Queensland, xxxiii., 1921, p. 57.

One male, paratype, from Brisbane, Queensland.

\section{Sarcophaga beta Johnston and Tiegs.}

S. beta Johnston and Tiegs, Proc. Roy. Soc. Queensland, xxxiii., 1921, p. 58.

One female, paratype, from Brisbane, Queensland.

\section{Sarcophaga peregrina R.D.}

Myophora peregrina Robineau-Desvoidy, Essai sur les Myodaires, 1830, p. 356.

Myophora subrotunda R.D., l.c., p. 357.

Myophora rapida R.D., l.c., p. 360.

Sarcophaga tritonia Macquart, Dipt. Exot. Suppl., iv., 1850, p. 234.

S. irrequieta Walker, List. Dipt. British Mus., 1849, iv., p. 830.

S. ochripalpis Thomson, Engenies Resa, Diptera, 1868, p. 537.

S. frontalis Johnston and Bancroft, Proc. Roy. Soc. Queensland, xxxii., 1920, p. 23.

S. irrequieta Johnston and Tiegs, Proc. Roy. Soc. Queensland, xxxiii., 1921, p. 63.

This is by far the commonest sarcophagid fly in South Eastern Queensland. Mr. A. P. Dodd informs us that it likewise predominates in the Cairns district, North Queensland. The Australian Museum specimens are chiefly from Sydney, but there are also a few from the Fly River, New Guinea.

It is but natural that the various entomologists who described our Sarcophagids, from Robineau-Desvoidy onwards, should have come across this insect, and as they gave little or no attention to each other's work, it is not surprising that a considerable synonymy has arisen. Furthermore, as the general body colour of the fly may vary considerably from pale golden to pure silvery, the confusion has become still greater. However, as this insect is easily recognised even without an examination of the male copulatory organs, we have no hesitation in giving the above synonymy. The differences on which the species referred to are founded are not greater than the amount of variation often seen in the offspring of a single parent, both in regard to size and colouration, while the sex differences are well enough defined to account for any apparent discrepancies in early descriptions.

That S. tritonia Macquart, is synonymous with S. peregrina is almost certain. The fly was described from Triton Bay, Dutch New Guinea, but as the brief description in every way fits S. peregrina, and since we have 
examined specimens of the latter species from British New Guinea, we are suggesting the synonymy, hoping thereby to reduce the confusion which the ambiguous accounts of early entomologists have produced.

\section{Sarcophaga eta Johnston and Tiegs.}

S. eta Johnston and Tiegs, Proc. Roy. Soc. Queensland, xxxiii., 1921, p. 65 .

One màle, paratype, bred from decaying fish, Brisbane, Queensland.

\section{Sarcophaga misera Walker.}

S. misera Walker, List. Dipt. British Museum, iv., 1849, p. 829.

S. frontalis Thomson, Engenies Resa. Diptera., 1868, p. 535.

S. frontalis (in part) Froggatt, Australian Insects, 1907, p. 314-5.

S. frontalis Tryon, Dept. Agric. Qld. Ann. Rep. $1916-7$ (1917), p. 53.

S. misera Cleland, Aus. Med. Congress, 1911 (1913), pp. 548, 570.

S. misera Johnston and Bancroft, Proc. Roy. Soc. Queensland, xxxii., 1920, p. 23.

S. misera Johnston and Tiegs, Proc. Roy. Soc. Queensland, xxxiii., 1921, p. 67.

A male from Victoria, a female from Sydney, New South Wales. The presence of fairly well-developed prescutellar acrostichal bristles should have been mentioned in our earlier account.

\section{Sarcophaga misera var. dux Thomson.}

S. dux Thomson, Eugenies Resa. Dipt., 1868.

S. subtuberosa Parker, Proc. U.S. Nat. Mus., liv., 1917, p. 89.

S. misera var. dux Johnston and Tiegs, Proc. Roy. Soc. Queensland, xxxiii., 1921 , p. 70.

One male, Brisbane, Queensland. A species (or variety) widely distributed throughout the Pacific.

\section{Sarcophaga aurifrons Macquart.}

S. aurifrons Macquart, Dipt. Exot. Supp., i., 1846, p. 191.

S. aurifera Brauer and Bergenstamm, Denkschr. Akad. Wiss. Wien., 1891.

S. aurifrons Tryon, Dept. Agric. Qld. Ann. Rep., 1916-17, p. 53.

S. aurifrons Froggatt, Agric. Gazette, N.S.W., xvi., 1905, p. 20.

S. aurifrons Froggatt, Austr. Insects, 1907, p. 315.

S. aurifrons Froggatt, N.S.W. Dept. Agric. Farmers' Bull. 95, 1915, p. 29.

S. aurifrons Johnston and Tiegs, Proc. Roy. Soc. Queensland, xxxiii., 1921 , p. 71.

A male and a female from Brisbane, Queensland. 
11. Sareophaga froggatti Taylor.

S. froggatti Taylor, Bull. Ent. Res., vii., 3, 1917, p. 265.

S. Knabi Parker, Proc. U. S. Nat. Mus., liv., 1917, p. 96.

S. aurifrons (in part) of Australian authors.

S. froggatti Johnston and Tiegs, Proc. Roy. Soc. Queensland, xxxiii., 1921, p. 73.

Glaucosarcophaga knabi Towsend, Proc. Biol. Soc. Washington, xxx., 1917 p. 191 (type of genus).

Glaucosarcophaga froggatti Johnston and Tiegs, Proc. Roy. Soc. Queensland, xxxiii., 1921, p. 76.

One male, Brisbane, Queensland.

\section{Sarcophaga theta Johnston and Tiegs.}

S. theta Johnston and Tiegs, Proc. Roy. Soc. Queensland, xxxiii., 1921, p. 78.

A male and a female, paratypes, Brisbane, Queensland.

\section{Sarcophaga depressa R.D.}

(Plate $\mathrm{xx}$., fig. 4.)

Myophora depressa Robineau-Desvoidy, Essai Myodaires, 1830, p. 353.

Myophora musca R.D., l.c., 1830, p. 360.

Sarcophaga flavifemorata Macquart, Dipt. Exot. Suppl. 4, 1850, p. 233.

Sarcophaga iota Johnston and Tiegs, Proc. Roy. Soc. Queensland, xxxiii., 1921, p. 79.

The specimens in the Australian Museum comprise four males and three females, captured at such widely separated localities as King George's Sound (S. W. Australia), Bagdad (Tasmania), Perth (W. A.), and Sydney (N.S.W.). It is quite common about Brisbane. As this is one of the commonest of the smaller golden sarcophagids, it is very probable that Robineau-Desvoidy had this species before him when he described $M$. depressa. The individual variations exhibited by this fly are sufficient to account for his describing it under two different names. As both his types were females, an examination of these, if they are still in existence, would be of little value, the female of this species being indistinguishable in external characters from the females of certain closely allied species. By adopting the above synonymy, the confusion resulting from the brief, more or less, general descriptions of early workers should be still further diminished. Macquart doubtless had this same species before him when he described S. flavifemorata from the east coast of Australia. As all the descriptions, as far as they go, apply to S. iota, recently described by us, and as this is the commonest small golden species in Australia, the synonymy as given above is probably correct. We give a figure of the terminal portion of the male genitalia. 
14. Sarcophaga kappa Johnston and Tiegs.

S. kappa Johnston and Tiegs, Proc. Roy. Soc. Queensland, xxxiii., 1921, p. 81.

One male, captured in Sydney, New South Wales.

15. Sarcophaga omitiron Johnston and Tiegs.

S. omikron Johnston and Tiegs, Proc. Roy. Soc. Queensland, xxxiii., 1921, p. 82.

One male, captured at Chinchilla, West Queensland, September, 1921.

16. Sarcophaga sigma Johnston and Tiegs.

S. sigma Johnston and Tiegs, Proc. Roy. Soc. Queensland, xxxiii., 1921, p. 84 .

A male and a female, paratypes, bred in Brisbane, Queensland, from decaying meat.

17. Sarcophaga gamma Johnston and Tiegs.

S. gamma Johnston and Tiegs, Proc. Roy. Soc. Queensland, xxxiii., 1921, p. 60 .

One male, paratype, caught on decomposing meat, Brisbane, Queensland, April, 1921.

18. Sarcophaga zeta Johnston and Tiegs.

S. zeta Johnston and Tiegs, Proc. Roy. Soc. Queensland, xxxiii., 1921, p. 76 .

One male, bred from decomposing meat, Brisbane, Queensland, October, 1921.

19. Sarcophaga epsilon n. sp.

(Plate $\times x \times v$., fig. 1.)

A rather large $\mathrm{fly}$, about $14 \mathrm{~mm}$. in length; in general appearance golden and black.

\section{MALE}

Head.-Front prominent, at its narrowest slightly over half the eyewidth; frontal stripe very dark brown, about as wide as parafrontals. The latter bright gold, with dark reflections; genæ similarly coloured. Eyes dark red brown. Mesofacial plates pale golden, with silvery pubescence, borders darker; back of head golden. First antennal joint distinctly visible, but not very large; second joint large, black; third joint black, and thrice the length of second. Arista nearly half as long again as the three antennal joints combined. 
Vibrissæ inserted well above oral margin ; about fifteen facial bristles present; eight epistomials. A row of thirteen frontal bristles on either side of frontal stripe. Verticals large; lateral verticals fairly well developed. A single row of black bristles behind eyes; back of head covered with short golden hairs, which develop into a beard-like growth below ; bristles on front part of cheeks short and black.

Thorax ashy-golden, with the usual three longitudinal black stripes, the outer two broader than the middle stripe. On either side of the middle stripe are a pair of narrow but very distinct stripes, gradually fading away on the posterior part of the thorax; external to the outer stripes occurs on each side on the posterior half of the thorax a longitudinal black marking. Scutellum very dark, nearly black, with golden borders. Anterior spiracle pale brown, covered with white hairs. Sides of thorax golden; lower surface grey. Only the posterior pair of the anterior acrostichals are developed; of the posterior set only the last two pairs are present; all are very feebly developed. Dorsocentral row normal. Three pairs of humerals present; two intra-alars. Scutellar apicals present.

Legs black and grey. First femur faintly tinged with gold ventrally. Longitudinal rows of bristles complete; provided ventrally with a rather thick growth of short hairs; tibia not hairy. Second femur very faintly tinged with gold; not hairy; a distinct "comb" present. Third femur grey; both femur and tibia hairless.

Abdomen silvery and black, as usual; covered dorsally with short black reclinate bristles; hairy ventrally. Hypopygium very dark brown, nearly black, hairy. Forceps shiny black and sharply pointed, very hairy. Anterior third of each closely approximated. Claspers very dark brown; anterior rather blunt; posterior sharp. The penis resembles that of Sarcophaga beta. The chitinisation is very heavy, the whole structure being quite black. Ventrally it is developed into a forwardly bent hook, which acts as a protection for a pair of curved chitinous processes, very similar to those of S. alpha.

Described from one male, captured by us around decaying meat in Brisbane, Queensland, July, 1921.

\section{Sarcophaga hardyi n. sp.}

$$
\text { (Plate } \mathrm{xxx} \text {., fig. 5.) }
$$

In general appearance a rather large golden and black insect, measuring $12 \mathrm{~mm}$. in length.

\section{MaLe.}

Head.-Frons rather prominent, half the width of eye; parafrontals pale golden in colour and provided with two very irregular rows of short black bristles; genæ and occiput a somewhat deeper gold. Frontal stripe brown, faintly silvery pollinose, and slightly wider than the parafrontals. First antennal joint fairly conspicuous; second slightly smaller than usual; third thrice the length of second, very dark brown and very strongly silvery pollinose. Arista over half as long again as the three 
antennal joints combined. A single row of short black bristles behind eyes. Occiput covered with short golden hairs, developed into a beardlike growth below, but shortening again on the anterior part of the genæ. A row of twelve frontal bristles on either side of frontal stripe. Verticals well developed; lateral verticals small. Vibrissæ inserted well above oral margin. About nine facial bristles present; an irregular row of nine extending from these along the borders of the mesofacial plate, just internal to the ptilinal suture, about half-way towards the insertion of the antennæ. Proboscis brown, in places nearly black; palps dark brown.

Thorax slightly narrower than head, golden with three longitudinal black stripes, the lateral pair curved faintly outwards and considerably wider than usual. The middle line extends very definitely on to scutellum; the laterals do not, but a short black mark on the posterior outer margin of the scutum is continued on to the scutellum. Microchætæ on thorax, especially on scutellum very strongly developed.

Of the anterior acrostichals only the last two pairs are differentiated, and are considerably larger than usual. Of the posterior set, only the prescutellar are developed; they extend over two-thirds the way to the posterior border of the scutellum. Row of dorsocentrals very well developed. Three humerals and three intra-alars present. A pical scutellars present. Anterior spiracle black with dark chocolate hairs. Sides of thorax grey, tinged with gold, very hairy. Ventral side grey.

Legs grey and black. First femur faintly tinged with gold. The longitudinal rows of bristles very complete; under side scantily clothed with long hairs; tibia slightly shorter than femur, and not hairy. Second femur slightly hairy on its proximal ventral half; "comb" very well differentiated; tibia a little shorter than femur and not hairy. Third femur and tibia hairy.

Abdomen provided dorsally with short reclinate bristles; hairy ventrally. Hypopygium black and very hairy. Forceps shiny black, the termination slightly hooked and sharply pointed; hairy almost to tips, the growth becoming very dense on the upper two-thirds. The penis is a rather complex structure; the distal joint is divided into an anterior and posterior portion, each provided with curious processes as figured. The nature of the claspers could not be observed in the specimen available.

\section{Female.}

This differs from the male in the following characters:- It is rather smaller, measuring about $10 \mathrm{~mm}$. in length. Frons a little wider than eyes. Frontal stripe about as broad as parafrontals. Frontal bristles arranged in an inner row of nine beside frontal stripe, and three above, just internal to eyes. Lateral verticals very prominent. Apical scutellars absent. Second femur not markedly hairy, "comb" absent. Third femur and tibia entirely devoid of hair.

Described from a male and a female collected by Mr. G. H. Hardy at Launceston, Tasmania, in October, 1916. 


\section{Sarcophaga littoralis n. sp.}

$$
\text { (Plate } x \times x v ., \text { fig. 2.) }
$$

In general appearance a medium-sized greyish fly, measuring some $10-11 \mathrm{~mm}$. in length.

\section{Male.}

Head._Frons fairly prominent, about three-fifths the width of eyes. Frontal stripe dark brown, about half as broad again as parafrontals, the latter silvery, faintly tinged with gold and with dark reflections; genæ pale brownish yellow; occiput silvery, faintly tinged with golden. Eleven frontals beside frontal stripe; verticals smaller than usual, lateral verticals absent. Vibrissæ small; seven very short, stout epistomials, and seven similar facials. These bristles are considerably stouter than any hitherto seen by us in Australian sarcophagids. A single row of short black bristles behind eyes; occiput covered with short silvery hairs which lengthen below, but become shorter again and more sparse on the anterior part of the geнæ. Eyes red brown, about three-fifths the height of head. First antennal joint conspicuous; second black, and smaller than usual; third about two and a half times the length of second, and of a fawn colour. Mesofacial plate very pale golden, with darker borders. Ptilinal suture remains fairly distinct throughout life.

Thorax grey; the middle longitudinal black line consists of three longitudinal portions anteriorly; posteriorly it is continued as a long narrow line, broadening out a little on the scutellum. Lateral lines irregular and not extending on to scutellum. Lateral and vertical regions of thorax grey; scutellum much abbreviated. Of the acrostichals, only the posterior pair of the anterior set is differentiated. Apical scutellars present. Dorsocentral row as usual. Two intra-alars and three humerals present.

Legs black, femora greyish. First femur not distinctly hairy ; tibia hairless. Second femur lightly hairy; a "comb" differentiated; tibia hairless. Third femur lightly hairy ; tibia hairless.

Abdomen black with greyish tesselations, the whole rather darker than usual. Abdomen covered dorsally with short reclinate bristles; hairy ventrally. Hypopygium black and hairy. Forceps black, hairy, and very distinctly humped, the upper halves closely approximated, the lower widely apart. Clasper's simple, and rather slender. The distal joint of the penis is heavily chitinised, and of a rather complex structure.

\section{Female.}

This closely resembles the male, but differs in the following characters:-Frons as wide as eyes; eyes four-sevenths the height of head. Vertical bristles present. Frontal stripe a little wider than parafrontals. The epistomials, facials and vibrissæ even more abbreviated than in male. Scutellar apicals absent. First femur very lightly hairy; second devoid of comb; third femur lightly clothed with golden hairs, tibia hairless.

Described from a male and a female captured on the ocean beach at Caloundra, South Queensland, August, 1921. 
22. Sarcophaga pallinervis Thomson.

(Plate xxxv., fig. 6).

MALE.

Head.-Frons not very prominent, measuring about two-fifths the width of eyes. Froutal stripe brown, about thrice the width of parafrontals. Parafrontals, occiput, and genæ silvery, with brown reflections. First antennal joint not very conspicuous; second black, tipped with brown; third only half as long again as second, dark brown and silvery pollinose. Mesofacial plate silvery, with dark borders. Vibrissæ inserted well above oral margin. Four facial bristles present, three others extending from these upwards half-way towards the antennal insertion. About thirteen well-developed epistomials present. A row of ten frontals beside the frontal stripe. Three distinct rows of bristles on back of head. Bristles on genæ black. Verticals very well developed, lateral verticals very weak. Thorax rather narrower than head, grey, with the usual three longitudinal black lines. Sides grey with a few black markings, ventral side grey. Scutellum grey. Anterior acrostichals very well developed; of the posterior set only the prescutellar pair sharply differentiated. Dorsocentral row complete. Apical scutellars absent. Three humerals present. Anterior spiracle provided with numerous white hairs.

Legs black. First femur slightly hairy; tibia devoid of hair. Second femur slightly hairy proximo-ventrally; distally a "comb" developed. Third femur only very slightly hairy proximally; tibia hairless.

Abdomen clothed dorsally with short reclinate bristles; ventral side less hairy than usual. Hypopygium pale reddish brown, slightly bristly. Forceps brown, hairy almost to tips, not curved. Claspers brown. The penis is a rather simple structure, very dark brown in colour, and the distal joint produced downwards into two short blunt bosses, while anteriorly it gives off a pair of short processes.

\section{Female.}

This differs from the male in the following characters:-Frons slightly broader than eyes. Frontal stripe almost twice the breadth of parafrontals. A row of eight frontals beside frontal stripe, four others beside the eye. Thoracic chætotaxy as in male. Second femur devoid of " comb." Third femur and tibia hairless.

Described from several males and females donated by Mr. H. Tryon, Government Entomologist, Queensland, bred in Oahu, Hawaii, from cow manure.

\section{Sarcophaga hamorrhoidalis Fallen.}

$$
\begin{gathered}
\text { (Plate } x x x v ., \text { fig. 3.) } \\
\text { MaLt. }
\end{gathered}
$$

In general appearance a rather large greyish fly, measuring nearly $14 \mathrm{~mm}$. in length.

Head.-Frons not very prominent, a little over half the width of eyes. Frontal stripe exceedingly broad, black, and measuring about thrice the width of the parafrontals. Parafrontals, occiput, and genæ dark grey. Eyes red-brown, about three-fifths the height of head. First 
antennal joint inconspicuous; second normal, rather black in colour; third joint over twice the length of second, dark brown, and silvery pollinose. Arista brown, a little longer than the three antennal joints combined. Vibrissa inserted well above oral margin. Mesofacial plate brown. Seven large and four small facial bristles present; about ten epistomials present. A row of eleven frontal bristles beside frontal stripe. Verticals rather small; lateral verticals not very strongly developed. Three rows of black bristles behind eyes, of which ouly the first is well developed. Occiput clothed with short silvery hairs, developing into a beard-like growth below; anterior part of genæ clad with short black bristles.

Thorax rather broader than head, grey with three longitudinal black stripes, the outer pair rather broader than usual. Sides dark grey; under side grey; spiracle black with dark chocolate hairs. Three humerals; three intra-alars; the anterior acrostichals are absent; of the posterior acrostichals only the prescutellar are developed, and these only very weakly. Apical scutellars present.

Legs black. First femur clad with long hairs on proximal ventral half; tibia shorter than femur; hairless. Second femur hairy on proximal ventral two-thirds, distal third develops a "comb"; tibia hairless. Third femur and tibia hairy.

Abdomen covered dorsally with short reclinate bristles; below hairy. Hypopygium reddish brown, covered with rather short black hairs. Forceps dark brown, only slightly bristly; distal half developed into a hook, sharply pointed. Accessory plate small, brown, and provided with a few bristles. Two pairs of very dark brown claspers present; the posterior pair the smaller. Penis dark brown and black. From its anterior portion two powerful hooks are given off, below which the penis is developed into a rather thick complex prominence.

The description is from a male donated by Mr. Henry Tryon;captured in Oahu, Hawaii.

\section{Sarcophaga milleri n. sp.}

(Fig. 1.)

S. impatiens Hudson (nec. Walker), Trans. N.Z. Inst., xxxiii., 1901, p. 62. S. impatiens Miller (nec. Walker), Jour. Agric. New Zealand, xxii., 1921, p. 7.

In general appearance a pale golden and black fly, 9-10 mm. in length.

\section{MaLe.}

Head-_-Frons not very prominent, measuring about three-fifths the width of the eyes. Eyes red-brown, three-quarters the height of the head. Parafrontals and genæ pale golden, occiput silvery, a silvery streak being continued right round the eyes. Frontal stripe black, a quarter as wide again as parafrontals. Mesofacial plate very dark silvery, with black reflection, its borders black. A row of ten frontals beside frontal stripe. Verticals prominent; lateral verticals absent. First antennal 
joint not very conspicuous; second prominent, black; third two and a half times the length of second. Epistome brownish. Vibrissæ large; eight facials and eleven epistomials. Palps and proboscis black. One very distinct line of black bristles behind eyes; these followed by numerous irregular rows on occiput and extending on to anterior part of genæ.

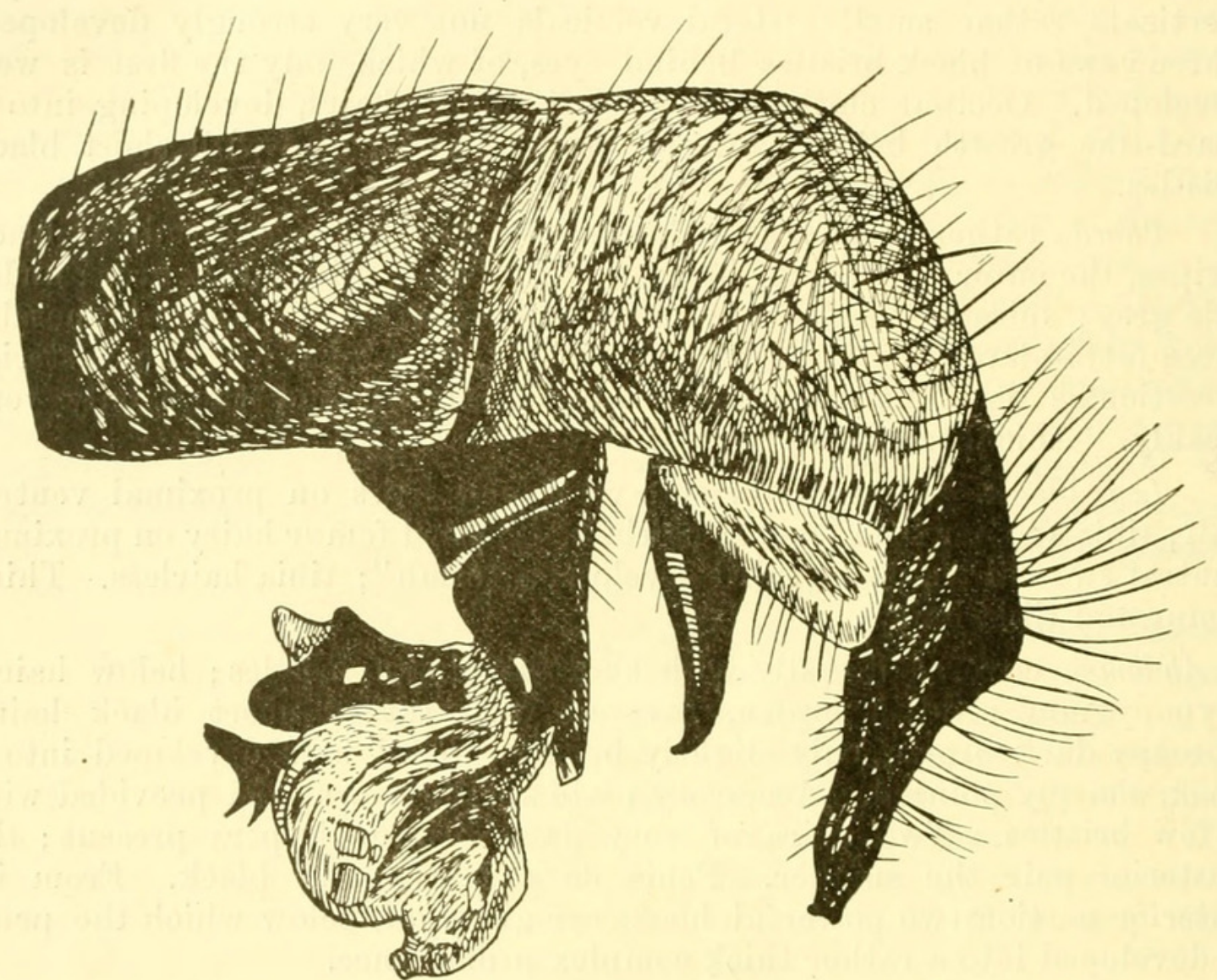

Fig. 1. Sarcophaga milleri n. sp. Male genitalia.

Thorax slightly wider than eyes, with three longitudinal black lines, of which the middle one alone extends on to scutellum. Lateral and ventral walls grey and golden. All the acrostichals are absent. Dorsocentral row complete; two intra-alars and three humerals. Anterior spiracle clothed with golden and chocolate hairs.

Legs black, femora tinged with grey on under side. First femur slightly hairy ventrally; tibia not hairy. Second femur hairy on proximal two-thirds; a very pronounced "comb" present. Third femur with a rather heavy growth of short hairs; tibia hairless.

Abdomen hairy below, clothed dorsally with very short black reclinate bristles. Abdomen black, the silvery tessellations practically absent. Both hypopygial segments black, covered with weak black bristles. Clasper's shiny black; the penis is a fairly heavily chitinised structure, black and brown in colour. Forceps nearly black; their upper internal portions are brown, and the colour is continued upwards to form a large brown triangular patch at the back of the hypopygium. Forceps hairy almost to tips; the ends not pointed but terminating in a small triradiate knob. 


\section{Female.}

This differ's from the male in the following characters:-Frontal stripe as broad as parafrontals. Six frontal bristles beside frontal stripe, and three beside eyes; lateral verticals prominent. Eyes about threefifths the height of head. Second femur not hairy, "comb" absent. Third femur and tibia hairless. Abdomen rounded, almost devoid of hairs ventrally.

Described from a male and a female from New Zealand sent to the authors by Mr. D. Miller, Government Entomologist, Wellington, New Zealand, and now deposited in the Australian Museum collection.

F. W. Hudson, in his synopsis of the Diptera Brachycera of New Zealand, recorded ${ }^{7}$ only one local Sarcophagid, which he reported as very common, and regarded as being identical with Sarcophaga impatiens Walker. The above-mentioned insects were sent to us under this designation, but even a superficial examination shows them to be quite distinct from Walker's species.

\section{Sarcophaga multicolor n. sp.}

(Fig 2.)

In general appearance a large golden and black fly $12 \mathrm{~mm}$. in length. MaLe.

Head.-Frons half the width of eyes, which are reddish brown. Frontal stripe black, a little wider than parafrontals, which are dark gold in colour. Genæ and occiput bright gold. Mesofacial plates golden, borders tinged with black; ptilinal fissure not very distinct. First antennal joint scarcely visible; second large and black; third fawn colour, and nearly thrice the length of second. Height of eyes threequarters that of head. A row of thirteen frontal bristles beside frontal stripe. A row of small black bristles immediately internal to the eye, the lowest two the largest. Verticals large; lateral verticals present but rather weak. Vibrissæ strong; about twenty facial bristles. A single row of black bristles behind eyes; an indistinct second row behind these towards the vertex of the head, but extending only a short way outwards. Hairs on occiput and genæ golden. Proboscis black with brownish tinge; palps black.

Thorax slightly wider than eyes; golden with the usual black stripes, of which the middle one alone extends on to the scutellum. The latter stripe much broader posteriorly than in front. Sides of thorax golden, tinged with black. Three humeral bristles present. Dorsocentral row as usual. Of the acrostichals only the prescutellar differentiated. Two intra-alars. A.pical scutellars present.

Legs black. First femur tinged ventrally with gold; clothed with long thin bristles, beside the ordinary strong ones, but devoid of true hairs. Tibia slightly shorter than femur and not hairy. First tarsal joint less than one-third length of tibia. Whole tarsus about equal in length to tibia. The second and third femora are jet black and quite devoid of the usual golden or grey tinge. On the second femur the

7 Hudson-Trans. N.Z. Inst., xxxiii., 1901, p. 62. 
longitudinal row of bristles, which so often is differentiated into a "comb," is confined to the distal half, but the shortened condition of the bristles characteristic of that structure does not occur here. Second tibia slightly shorter than femur, hairless. Third femur distinctly hairy.

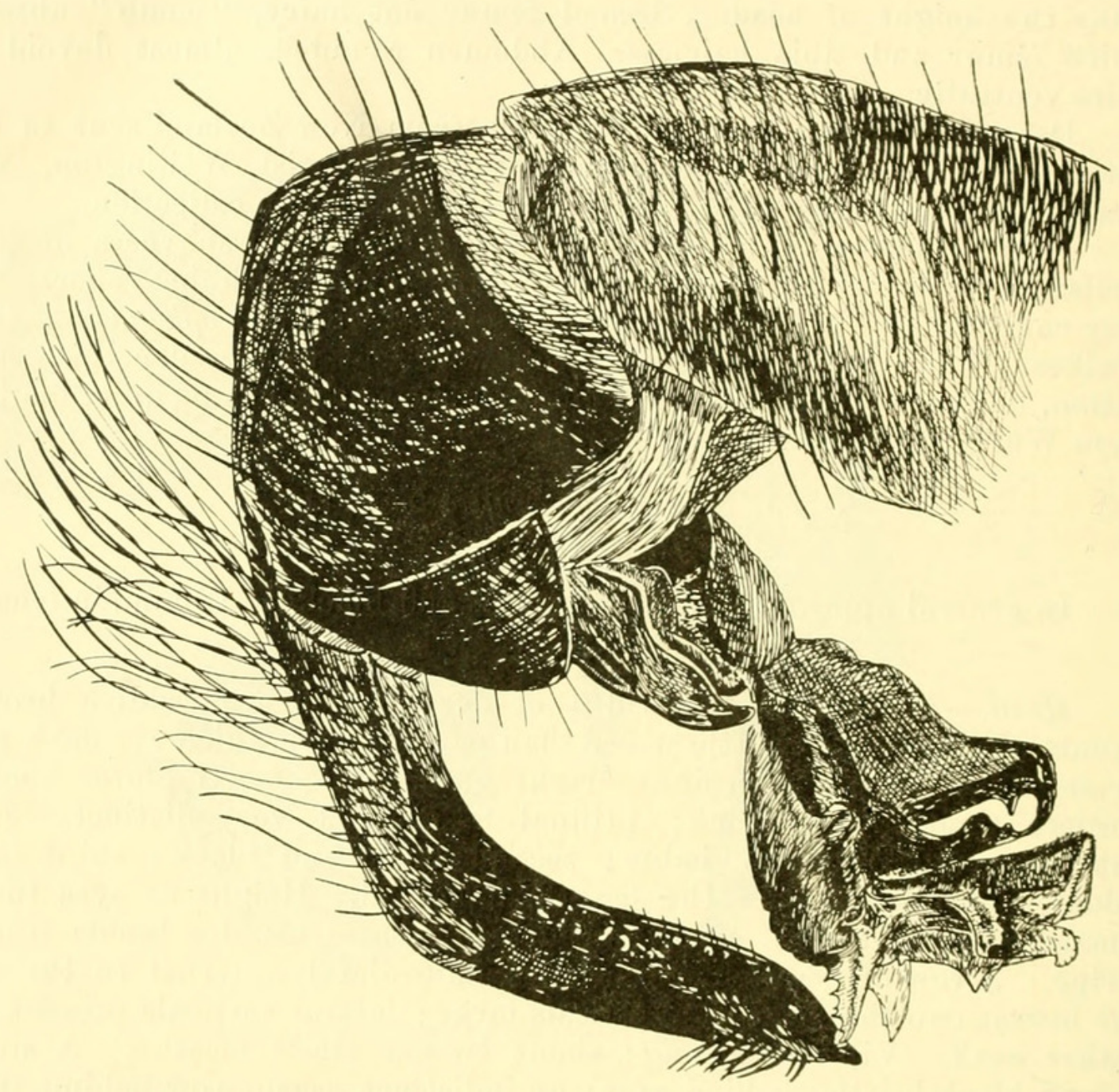

Fig. 2. Sarcophaga multicolor n. sp. Male genitalia.

Abdomen black and white as usual; the dark markings on the two segments immediately preceding the hypopygium, with a faint purplish tinge. Abdomen clothed with the usual reclinate bristles above, and with short hairs below, weakly in front, strongly behind. Hypopygial segments very dark brown, nearly black, clothed strongly with hairs, rather shorter than usual. Forceps shiny black, very faintly sculptured, sharply pointed, and distinctly curved. Termination armed with numerous short stout bristles; proximal half clothed with a scanty growth of rather long hairs. Accessory plate brown, not very prominent. Claspers brown. Proximal segment of penis brown, black posteriorly. The distal segment very large and exceedingly complex, possessing several distinct and in places strongly serrated processes. The form and arrangement of these structures is shown in Figure 2.

Described from a single male in the Australian Museum collection from Rabaul, New Britain. 
EXPLANATION OF PIATE XXXV.

Fig. 1. Sarcophaga epsiton n. sp., male genitalia.

,2. S. littoralis n. sp., male genitalia.

„3. S. hamorrhoidalis Fallen, male genitalia.

, 4. S. depressa R. D., male genitalia.

, 5. S. hardyi n. sp., male genitalia.

, 6. S. pallinervis Thomson, male genitalia. 

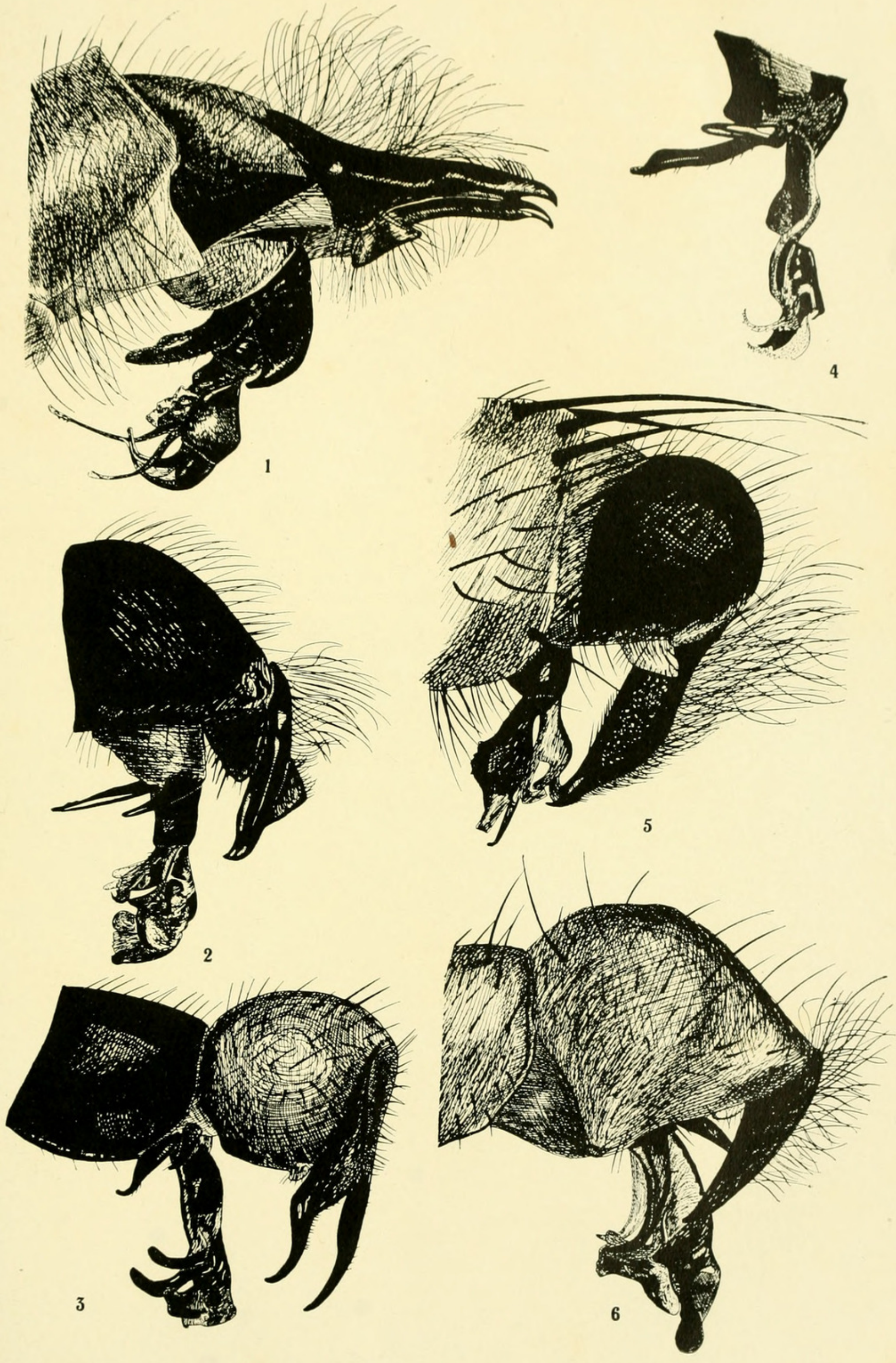

O. W. Tiegs, del. 


\section{$2 \mathrm{BHL}$ Biodiversity Heritage Library}

Johnston, T Harvey. 1922. "Sarcophagid flies in the Australian Museum." Records of the Australian Museum 13, 175-188. https://doi.org/10.3853/j.0067-1975.13.1922.869.

View This Item Online: https://www.biodiversitylibrary.org/item/36173

DOI: https://doi.org/10.3853/j.0067-1975.13.1922.869

Permalink: https://www.biodiversitylibrary.org/partpdf/20622

\section{Holding Institution}

MBLWHOI Library

\section{Sponsored by}

MBLWHOI Library

\section{Copyright \& Reuse}

Copyright Status: NOT_IN_COPYRIGHT

This document was created from content at the Biodiversity Heritage Library, the world's largest open access digital library for biodiversity literature and archives. Visit BHL at https://www.biodiversitylibrary.org. 